IZA DP No. 4625

Why Are Economics Students

More Selfish than the Rest?

Yoram Bauman

Elaina Rose

December 2009 


\title{
Why Are Economics Students More Selfish than the Rest?
}

\author{
Yoram Bauman \\ University of Washington \\ Elaina Rose \\ University of Washington \\ and IZA
}

\section{Discussion Paper No. 4625 \\ December 2009}

\author{
IZA \\ P.O. Box 7240 \\ 53072 Bonn \\ Germany \\ Phone: +49-228-3894-0 \\ Fax: +49-228-3894-180 \\ E-mail: iza@iza.org
}

\begin{abstract}
Any opinions expressed here are those of the author(s) and not those of IZA. Research published in this series may include views on policy, but the institute itself takes no institutional policy positions.

The Institute for the Study of Labor (IZA) in Bonn is a local and virtual international research center and a place of communication between science, politics and business. IZA is an independent nonprofit organization supported by Deutsche Post Foundation. The center is associated with the University of Bonn and offers a stimulating research environment through its international network, workshops and conferences, data service, project support, research visits and doctoral program. IZA engages in (i) original and internationally competitive research in all fields of labor economics, (ii) development of policy concepts, and (iii) dissemination of research results and concepts to the interested public.
\end{abstract}

IZA Discussion Papers often represent preliminary work and are circulated to encourage discussion. Citation of such a paper should account for its provisional character. A revised version may be available directly from the author. 
IZA Discussion Paper No. 4625

December 2009

\section{ABSTRACT}

\section{Why Are Economics Students More Selfish than the Rest?*}

A substantial body of research suggests that economists are less generous than other professionals and that economics students are less generous than other students. We address this question using administrative data on donations to social programs by students at the University of Washington. Our data set allows us to track student donations and economics training over time in order to distinguish selection effects from indoctrination effects. We find that economics majors are less likely to donate than other students and that there is an indoctrination effect for non-majors but not for majors. Women majors and nonmajors are less likely to contribute than comparable men.

JEL Classification: A13, D64

Keywords: $\quad$ altruism, public goods

Corresponding author:

Elaina Rose

Department of Economics

Mail Code 353330

University of Washington

Seattle, WA 98195

USA

E-mail: erose@u.washington.edu

\footnotetext{
* We thank Susana Angkico of the UW registrar's office for help with the data set, participants in a seminar at UC Davis for helpful comments, and Wolfram Latsch for helpful conversations.
} 


\section{Introduction}

There is a common belief-supported by the bulk of the relevant academic literature-that economists are less generous than other professionals and that economics students are less generous than other students. But why are economists more selfish? One possibility is selection, i.e., that more selfish individuals choose to become economics majors. Another possibility is indoctrination, i.e., that training in economics encourages students to emulate the homo economicus found in microeconomics texts.

Our contribution to this literature comes from an analysis of voluntary contributions to social programs by University of Washington undergraduates, who are offered an opportunity to make such contributions when they register each quarter. We find that economics majors are less generous than students majoring in a non-economics discipline within the College of Arts and Sciences (A\&S), and that this lack of generosity is due to selection, not indoctrination. But we also find an indoctrination effect for nonmajors: voluntary giving by non-majors—but not by majors—declines significantly after exposure to economics instruction Section II provides background on the empirical work on differences in the propensity of economists relative to non-economists to give. Section III describes the data, Section IV provides a descriptive analysis, and Section V outlines the empirical model. Section VI describes and discusses the results. In addition to the findings regarding economics training and major discussed above, we find that women, international students, and minority students are less likely to contribute than their complements. 


\section{Background}

Inquiry into the question of whether economists are less apt to engage in what Frey and Meyer (2004) refer to as pro-social behavior begins with Marwell and Ames (1981), who find that economics graduate students are more likely than other groups to free ride in a public-goods experiment. Additional experiments produced similar results: economics students offer less in ultimatum games (Carter and Irons 1991), they are more likely to defect in prisoners' dilemma games (Frank, Gilovich and Regan 1993), they are more likely to defect in a solidarity game (Selten and Ockenfels 1998), and they are more likely to accept bribes (Frank and Schulze 2000).

Other research relies on survey data. Rubenstein (2009) describes various business scenarios and asks students, as hypothetical employers, to make a series of decisions with respect to their employees; he finds that economics students are more likely to place profit maximization ahead of the welfare of the workers. Economists among Frey and Pommerehne's (1993) and Haucap and Just's (2003) survey respondents are more apt to view allocation based on prices as a fair mechanism for allocation.

Two studies come to the opposite conclusion, finding that economists are more likely to engage in pro-social behavior than others. First, Laband and Beil (1999) study dues payments to professional associations and find that "professional economists are significantly more honest/cooperative than professional political scientists, and especially, professional sociologists." Second, Yezer et al. (1996) conduct a "lost-letter" experiment by leaving envelopes containing cash in classrooms and find that students in upper-level economics classes are more likely than students in other upper-level classes to return the envelopes. The Laband and Beil result could, however, stem from income differences 
between professions, or from differences in membership benefits. The Yezer et al. study the sample sizes are small $(\mathrm{N}=64)$ and the differences are only marginally significant.

With one exception, previous studies such as the ones above use data from classroom experiments, surveys, or other fairly artificial environments. The exceptionFrey and Meier (2003), in a real-world situation similar to ours-uses administrative data on student contributions to social funds at the University of Zurich (UZ). (See also Frey and Meier 2004 and Benz and Meier 2008.) Students at UZ are asked at registration each semester if they want to contribute the equivalent of $\$ 4.20$ to a "loan fund" that provides loans to needy students, and also if they want to contribute the equivalent of $\$ 3$ to a "foreigner fund" that assists foreign students. Frey and Meier compare students of political economy (known to Americans as "economics") with students of business economics (known to Americans as "business administration") and students from other disciplines; their conclusion is that only the business economists behave more selfishly than others, and that this behavior is the result of selection rather than indoctrination.

The major structural difference between Frey and Meier's UZ study and our study at the University of Washington (UW) is that the UZ data set shows students taking a prescribed series of classes at prescribed points during their programs: economics students take the economics sequence, law students take the law sequence, etc., without much flexibility. In contrast, the UW data set displays greater variability, with students from different majors taking economics classes at different points during their studies. Because our data set contains both year of study (freshman, sophomore, etc.) as well as the quarter and academic year each student was enrolled in each class, we can distinguish the 
effects of economics training from the effects of general year-to-year progress. This allows for a crisp test of the selection and indoctrination hypotheses using observed data.

\section{Data}

Our data set, obtained from the UW registrar, covers the 8,743 undergraduate Arts and Sciences students aged 17-23 who registered between summer quarter 1999 (what we will call Q1) and spring quarter 2002 (Q12) and who had a declared major at the end of this sample window. This yields a panel data set of 65,044 observations. In addition to each student's declared major, the administrative data set includes the quarter (if any) in which each student took introductory or intermediate microeconomics at UW. ${ }^{2}$

Sample statistics are reported in Table 1 . Some $8 \%$ of the students were economics majors, a grouping in which we include double-majors; we use the label "other A\&S majors" to refer to the $92 \%$ who declared an Arts and Sciences major other than economics. Of the total sample, $32 \%$ took introductory microeconomics—and 7\% took intermediate microeconomics - at some point before the end of the study period. Approximately $61 \%$ of the students were women, $2 \%$ were black, $21 \%$ were Asian, and $2 \%$ were international students.

Our data set includes quarterly records on voluntary contributions by each student to "qualifying groups" that are recognized by the university. Two such groups existed

\footnotetext{
2 We can tell if a student took one of these classes at UW prior to our study period, but we cannot tell if a student took one of these classes prior to attending UW. We address this limitation with a robustness test described in Section V.
} 
during our study period: the Washington Public Interest Research Group (WashPIRG) and Affordable Tuition Now (ATN).

WashPIRG is a left-leaning activist group whose mission is "to deliver persistent, result-oriented public interest activism that protects consumers, encourage a fair, sustainable economy, and foster responsive, democratic government" ( WashPIRG 2009). WashPIRG has been a qualifying group at UW since 1976.

ATN is a group that lobbied for "sensible tuition rates, quality financial aid, and adequate funding of colleges at both the state and federal level(s)" (ATN 2005). ATN became a qualifying group following a petition drive and student body election in spring quarter 2000, so the registration period before summer quarter 2000 (Q5) was the first one in which students were solicited for a donation to ATN. During our sample period, $27 \%$ of students donated at least once to WashPIRG and 34\% donated at least once to ATN.

The solicitation process for qualifying groups occurs when students register for classes prior to the coming quarter. ${ }^{3}$ During the registration process, each student is asked if he or she wants to add (for example) an additional $\$ 3$ to their tuition bill to support WashPIRG. There is some evidence that students understand their choices and behave in accordance with economic principles: UW historical data indicate that when the requested donation for WashPIRG increased from \$2 in winter 1994 to \$3 in spring 1994 the

${ }^{3}$ From the start of our study period through winter quarter 2000 (Q3), the registration process took place via an automated telephone system called STAR. This system was replaced by online registration in October 2002 (Q14), but from spring quarter 2000 (Q4) through the remainder of our study period (Q12) students could register either via telephone or online (Rosen 2002). 
percentage of students who donated fell from $11.6 \%$ to $10.1 \%$, suggesting a price elasticity of demand of about $-0.34 .^{4}$

Figures 1 and 2 show the donation rates for WashPIRG and ATN during our study period. The low donation rates during summer quarters (Q1, Q5, and Q9) and during the first two quarters of ATN's existence are noteworthy, but what really stands out in all quarters is that University of Washington (UW) donation rates pale in comparison to the University of Zurich (UZ) donation rates in Frey and Meier (2003). An average of $61 \%$ of UZ students contribute to both funds each semester, while at UW the giving percentage each quarter averages $14 \%$ for ATN and $10 \%$ for WashPIRG. This result could be because of differences in how the requests are made (Frey and Meier [2004] note that "the manner in which one is asked to donate is crucial") or differences in for what the requests are made (perhaps students are keen to give to scholarship funds and less keen to support political activities) or differences in from whom the requests are made (perhaps there are differences between Swiss and American students), but differences in "university culture" are definitely not responsible: the same large differences show up when looking at decisions made by incoming first-year students. ${ }^{5}$

\footnotetext{
${ }^{4}$ In addition to the 1999-2002 panel data that is the focus of our paper, we also have aggregate data on student donations from 1992-2001 (Holm 2002). During our study period the contribution request each quarter was $\$ 3$ for WashPIRG and \$2 for ATN.

${ }^{5}$ Looking only at students during their freshman year at UW, we find that $10 \%$ of students who eventually become economics majors donate to ATN and 5\% of these students donate to WashPIRG; the comparable percentages for students who eventually choose another Arts and Sciences major are 18\% for ATN and 12\% for WashPIRG. The differences between majors and non-majors are significantly different for both funds.
} 


\section{Descriptive Analysis}

Figures 3 and 4 show the percentage of economics majors and other A\&S majors who donated to WashPIRG and ATN during quarters in which they had no prior exposure to microeconomics at UW (group 1), during quarters in which they had prior exposure to introductory microeconomics but not intermediate microeconomics (group 2), and during quarters in which they had prior exposure to both introductory and intermediate microeconomics (group 3). These figures suggest that economics majors are less generous than other Arts and Sciences majors. About 5\% of economics majors donate to WashPIRG in a given quarter, compared with $8 \%$ for other majors. A similar divide-10\% versus over $14 \%$ - occurs with respect to donations to ATN.

Figures 3 and 4 also show that exposure to microeconomics appears to have a significant effect on generosity for other Arts and Sciences majors but little effect on generosity for economics majors. For the former group, the likelihood of donating to WashPIRG falls from about $12 \%$ prior to studying introductory microeconomics to about $9 \%$ afterwards. There is also a marked decline in these students' propensity to donate to ATN at each juncture: nearly $17 \%$ donated prior to taking any economics, only $13 \%$ donated after taking introductory microeconomics, and less than $9 \%$ donated after taking intermediate microeconomics. Relative to other A\&S students, economics majors are much less likely to give prior to studying economics, but their donation rates appear to be unaffected by exposure to economics courses. 


\section{Empirical Model}

To test whether economics majors are inherently less generous than other Arts and Sciences majors and whether studying economics discourages students from being generous we estimate the following model:

$$
\operatorname{Pr}\left(\text { Donate }_{\mathrm{QQ}}\right)=\alpha+\beta \text { Econ }_{\mathrm{i}}+\gamma_{\text {Intro }} \text { Intro }_{\mathrm{iQ}}+\gamma_{\text {Inter }} \text { Intermediate }_{\mathrm{iQ}}+X_{\mathrm{iQ}} \theta+\xi_{\mathrm{iQ}}
$$

In this model "i" refers to student and "Q" indicates quarter (Q1 through Q12). A student who donates in (say) Q2 is a student who donates at the end of Q2, i.e., during registration for Q3. Econ indicates that the student is an economics major; the default category is other majors in Arts and Sciences. Intro and Intermediate are dummy variables indicating that the student had registered in introductory or intermediate microeconomics by the end of the prior quarter. The set of controls, $X$, includes dummy variables for sex, race, year of birth, quarter, year in the program, and whether the student is an international student.

Column (1) of Table 2 reports estimates of equation (1) where the dependent variable is the likelihood of donating to WashPIRG and Intro and Intermediate are excluded. Field of study matters: economics majors are about 5.6 percentage points less likely to donate than other Arts and Sciences majors.

Are economics majors inherently less generous, or are the differences due to their training? We answer this question in terms of the random effects model in columns (2). According to the random effects model, students are about 2.1 percentage points less likely to donate to WashPIRG after having taken introductory microeconomics; there is no 
evidence that intermediate microeconomics affects the likelihood of donating. The estimated effect of Econ remains significant even after controlling for students' exposure to economics. The effects of economics training, when estimated under fixed effects (column 3 ), are similar to the random effects estimates: students are about 1.7 percentage points less likely to donate after taking introductory microeconomics, and there is no evidence that taking intermediate microeconomics affects the propensity to donate.

We repeat the prior analysis with respect to ATN and report the results in columns (4) through (6). For the most part, the ATN results are qualitatively similar to those for WashPIRG. Depending on specification, we find that economics majors are between 3.6 and 6.4 percentage points less likely to donate than other A\&S majors. Estimates of the effect of Intro range from 1.6 to 2.9 percentage points. One difference between the WashPIRG and ATN results is that students are about 2.3 percentage points less likely to contribute to ATN after having taken intermediate microeconomics.

The negative coefficient on "Female" for both WashPIRG and ATN indicates that women are less generous than men: women are about 2 percentage points less likely than men to contribute to WashPIRG and 3.7 percentage points less likely to contribute to ATN. Given the ambiguous findings in the literature on gender and generosity in classroom experiments (e.g., Andreoni and Vesterlund 2001, Eckel and Grossman 1998, 2008), it is noteworthy that our results echo those of Frey and Meier (2003).

White students and students from later-born cohorts are more likely to donate than others. International students, who have less stake in the social programs, are less likely to donate. We would expect, particularly with respect to ATN, that each individual students 
would donate less over time because of the narrowing window of opportunity for that student to realize the benefits from their donations. However, there is little evidence that this is the case; indeed, freshmen are less likely to donate to WashPIRG than students in other years.

\section{Differences by Program}

The results reported in Table 2 indicate that economics majors are markedly less likely to donate than other A\&S majors. This suggests that there might be other respects in which donation behavior differs between the groups. We therefore disaggregate with respect to major; the results, reported in Table 3, confirm the impression from Figures 3 and 4 that other A\&S majors become less generous as they are exposed to economics.

It appears that only non-majors are impacted by studying economics. Fixed effects estimates indicate that taking introductory microeconomics reduces their likelihood of donating to WashPIRG by 2.0 percentage points. Taking intermediate microeconomics reduces their likelihood of donating to WashPIRG by 3.7 percentage points and to ATN by 7.9 percentage points. The effect of Intro on donation to ATN is significantly negative but no significant effect is detected in the fixed effects specification. Other coefficients reinforce the findings from the pooled analysis in Table 2: men, domestic students, whites, and laterborn cohorts are more likely to donate than their complements.

The Table 3 results suggest that economics majors respond differently to economics classes than do other Arts and Sciences majors. But are these differences significant? We answer this question in terms of the interacted specification: 


$$
\begin{aligned}
& \operatorname{Pr}\left(\text { Donate }_{\mathrm{iQ}}\right)=\alpha+\beta \text { Econ }_{\mathrm{i}}+\gamma_{\mathrm{Intro}} \text { Intro }_{\mathrm{iQ}}+\gamma_{\mathrm{Inter}} \text { Intermediate }_{\mathrm{iQ}}+ \\
& \quad+\delta_{\mathrm{Econ} \_ \text {Intro }} \text { Econ }_{\mathrm{i}}{ }^{*} \text { Intro }_{\mathrm{iQ}}+\delta_{\mathrm{Econ} \_ \text {Inter }} \text { Econ }_{\mathrm{i}}{ }^{*} \text { Intermediate }_{\mathrm{iQ}}+X_{\mathrm{iQ}} \theta+\xi_{\mathrm{iQ}}
\end{aligned}
$$

where the effects of taking each of the two economics courses are allowed to differ by major. The results are reported in Table 4.

The responses of majors and non-majors to training are significantly different, with the latter group showing a greater responsiveness to exposure to economics courses. According to the random effects specification, the negative effect of taking introductory microeconomics on donations to WashPIRG is 1.4 percent lower, in absolute value, for majors relative to non-majors. The fixed effects estimates indicate that the effect of taking intermediate microeconomics is 3.6 percent lower in absolute value.

Economics training has a similar smaller effect on donations to ATN for majors relative to non-majors. Estimates of the magnitudes of the differences in the effects of intermediate microeconomics range from 5.9 to 6.6 percentage points, depending on specification. The fixed effects results indicate that the response to introductory microeconomics is 3.2 percent lower for majors.

As mentioned in Section III, our data set reports the date of enrollment in introductory and intermediate microeconomics at UW, but it does not report possible exposure at other institutions. We can infer that a student who enrolled in intermediate microeconomics at UW without taking introductory microeconomics at UW must have taken that prerequisite prior to attending UW, but we cannot tell if a student who did not take either class at UW took either class prior to UW. So as a robustness test we restrict our 
sample to students classified as freshmen at UW for at least three quarters; these students were unlikely to have taken college courses elsewhere.

The results of this robustness test are reported in Table 5. The overall impression is similar to that from the full-sample results, but there are some differences. For non-majors, the effect of taking intermediate microeconomics on WashPIRG donations is much more pronounced for the restricted sample (a decline of about 13 percentage points) than for the full sample (a decline of about 4 percentage points). Once again, the overall effect of taking intermediate is completely counteracted by a coefficient of about 13 percent on the interaction term Econ_Inter. That is, there is no significant effect of taking intermediate economics on majors' donations.

The ATN results for the restricted sample are not significant, perhaps because the restricted sample is only one-third the size of the full sample.

\section{Conclusion}

Other research—notably Allgood et al. (2004), who report that "former students, especially those who did not major in economics, are not particularly impressed with how important much of the content in our courses is, or with how the courses are taught"supports the conclusion that undergraduate economics courses are bad. Our results lend weight to a different concern, namely that undergraduate economics courses are a public bad. Our real-world data set reveals that students who are not economics majors are less 
likely to contribute to social programs after studying economics than they were beforehand. This effect appears only for non-majors, not for majors.

One interpretation of these results is that students who are not economics majors suffer a "loss of innocence" during economics classes because of exposure to certain ideas (the prisoners' dilemma or the invisible hand) or because of exposure to certain people (namely, economics majors). In contrast, students who become economics majors do not suffer a loss of innocence. This may be because they lost their innocence in high schoolFrey and Meier (2003) find that pre-university exposure to economics reduces giving-or perhaps even because economics majors were "born guilty".

A heavy-handed reading of our findings might suggest that non-majors should be prohibited from studying economics, but because economics classes offer benefits as well as costs we come to a different conclusion, namely that introductory courses should do more to cover topics such as altruism and reciprocal behavior. Profit-maximization is a fine assumption for businesses, but a narrowly defined "selfish" version of utility maximization is neither accurate nor appropriate for modeling individual behavior.

As a final note it is worth pointing out that training students in this "selfish" version of utility maximization may be a private bad as well as a public bad. Recent research demonstrates that more generous individuals fare better in terms of a variety of outcomes. Dohman et al. (2009) find that those reporting greater propensity for positive reciprocal behavior do better in the labor market, e.g., they earn more and they are less likely to be unemployed. Konow and Early (2009) use a dictator game to show that selfish behavior is associated with lower psychological well-being, lower material well-being and less overall 
happiness than selfless behavior. These studies present some support for what is called the hedonistic paradox: behaving as homo economicus does not appear to be individually optimal. The paradox may of course be explained by unobservable differences in personality characteristics. But to the extent that these characteristics are the result of nurture rather than nature, training students in ways that make them more self-interested makes them worse off. 


\section{References}

Allgood et al. 2004. "What students remember and say about college economics years later." American Economic Review 94(2): 259-265.

Andreoni, James, and Lise Vesterlund 2001. "Which is the fair sex? Gender differences in altruism", Quarterly Journal of Economics, 116: 293-312.

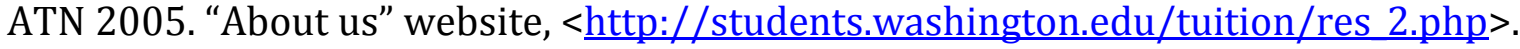
Accessed June 15, 2009.

Beil, Richard O., and David N. Laband, 1996. "The American Economic Association dues structure", Journal of Economic Perspectives 10:179-186.

Benz, Matthias, and Stephan Meier, 2008. "Do people behave in experiments as in the field? Evidence from donations", Experimental Economics 11:268-281.

Carter, John R., and Michael D. Irons, 1991. "Are economists different, and if so, why?" Journal of Economic Perspectives 5:171-177.

Dohmen, Thomas, Armin Falk, David Huffman and Uwe Sunde, 2009. "Home Reciprocans: Survey Evidence on Behavioural Outcomes”, Economic Journal 119: 592-612.

Eckel, Catherine C., and Philip J. Grossman, 1998. "Are women less selfish than men? Evidence from dictator experiments", Economic Journal 108: 726-735.

Eckel, Catherine C., and Philip J. Grossman, 2008. "Differences in the economic decisions of men and women: Experimental evidence", in C. R. Plott and V. L. Smith (ed.) Handbook of Results in Experimental Economics, North Holland/Elsevier Press.

Frank, Bjorn and Gunther G. Schulze, 2000. "Does economics make citizens corrupt?" Journal of Economic Behavior and Organization 43:101-113.

Frank, Robert H., Thomas Gilovich, and Dennis T. Regan, 1993. "Does studying economics inhibit cooperation?" Journal of Economic Perspectives 7:159-171.

Frank, Robert H., Thomas D. Gilovich, and Dennis T. Regan, 1996. “Do economists make bad citizens?" Journal of Economic Perspectives 10:187-192.

Frey, Bruno S. and Stephan Meier, 2003. "Are political economists selfish and indoctrinated? Evidence from a natural experiment", Economic Inquiry 41:448-462.

Frey, Bruno S. and Stephan Meier, 2004. "Pro-social behavior in a natural setting", Journal of Economic Behavior and Organization 54:65-88.

Frey, Bruno S. and Werner W. Pommerehne 1993 “On the Fairness of Pricing -- An Empirical Survey among the General Population" Journal of Economic Behavior and Organization 20:295-307. 
Gintis, Herbert. 2000. "Strong Reciprocity and Human Sociality." Journal of Theoretical Biology, 206:269-79.

Holm, Jeanne, 2002. Assistant Vice President for Student Affairs, personal communication, March 13.

Konow, James and Joseph Early, 2008. "The Hedonistic Paradox: Is Homo Economicus Happier?" Journal of Public Economics 92:1-33.

Laband, David N., and Richard O. Beil, 1999. "Are economists more selfish than other 'social' scientists?" Public Choice 100:85-101.

Marwell, Gerald, and Ruth E. Ames, 1981. "Economists free ride, does anyone else?" Journal of Public Economics 15: 295-310.

Rosen, Scott, 2002. "A STAR dies." University of Washington Daily, Oct. 31. Online at http://dailyuw.com/2002/10/31/a-star-dies/.

Selten, R., Ockenfels, A., 1998. "An experimental solidarity game". Journal of Economic Behaviour and Organization 34, 517- 539.

Yezer, Anthony M., Robert S. Goldfarb, and Paul J. Poppen, 1996. “Does studying economics discourage cooperation? Watch what we do, not what we say or how we play", Journal of Economic Perspectives 10:117-186. 

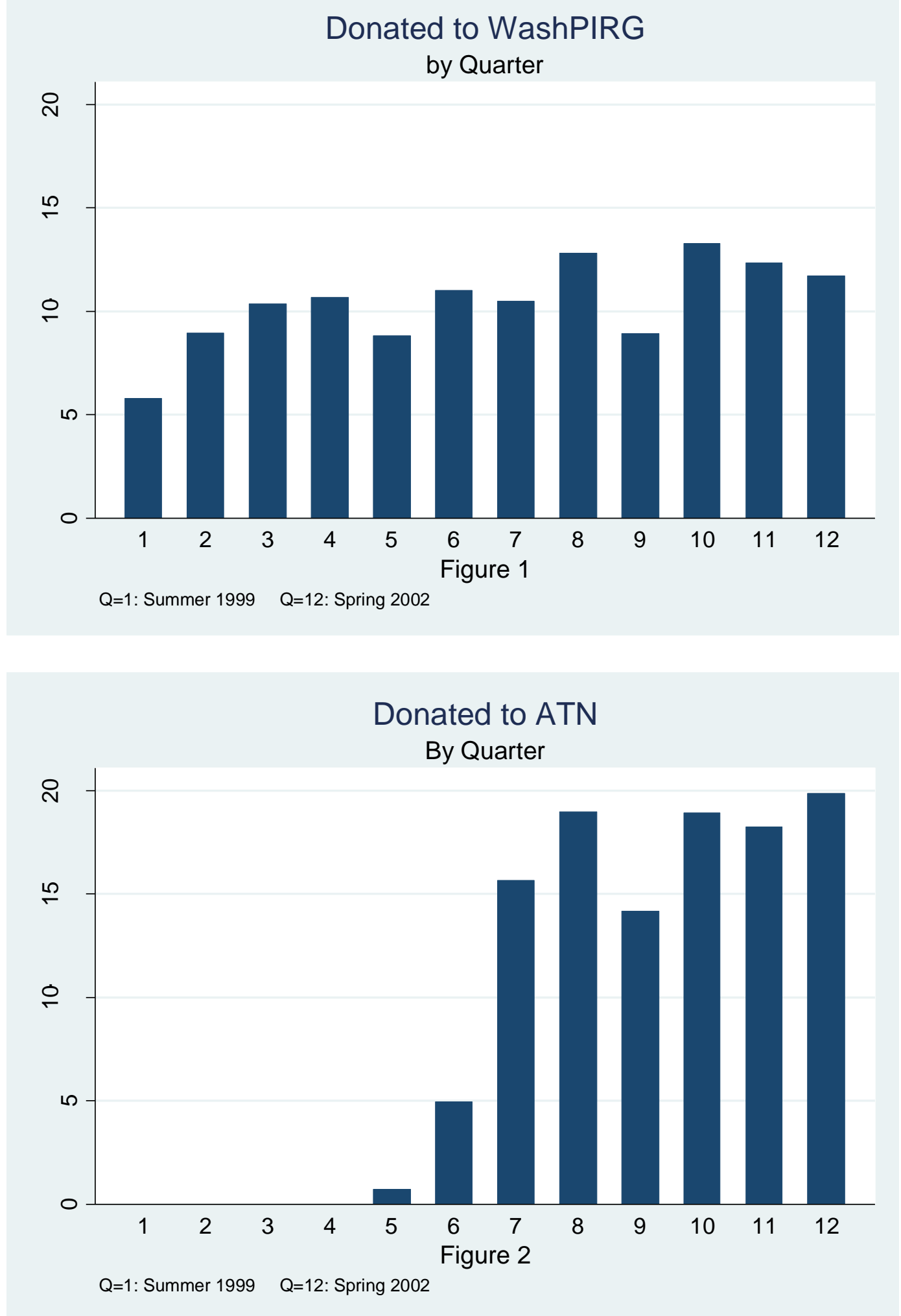


\section{Donated to WashPIRG}

By Program and Training

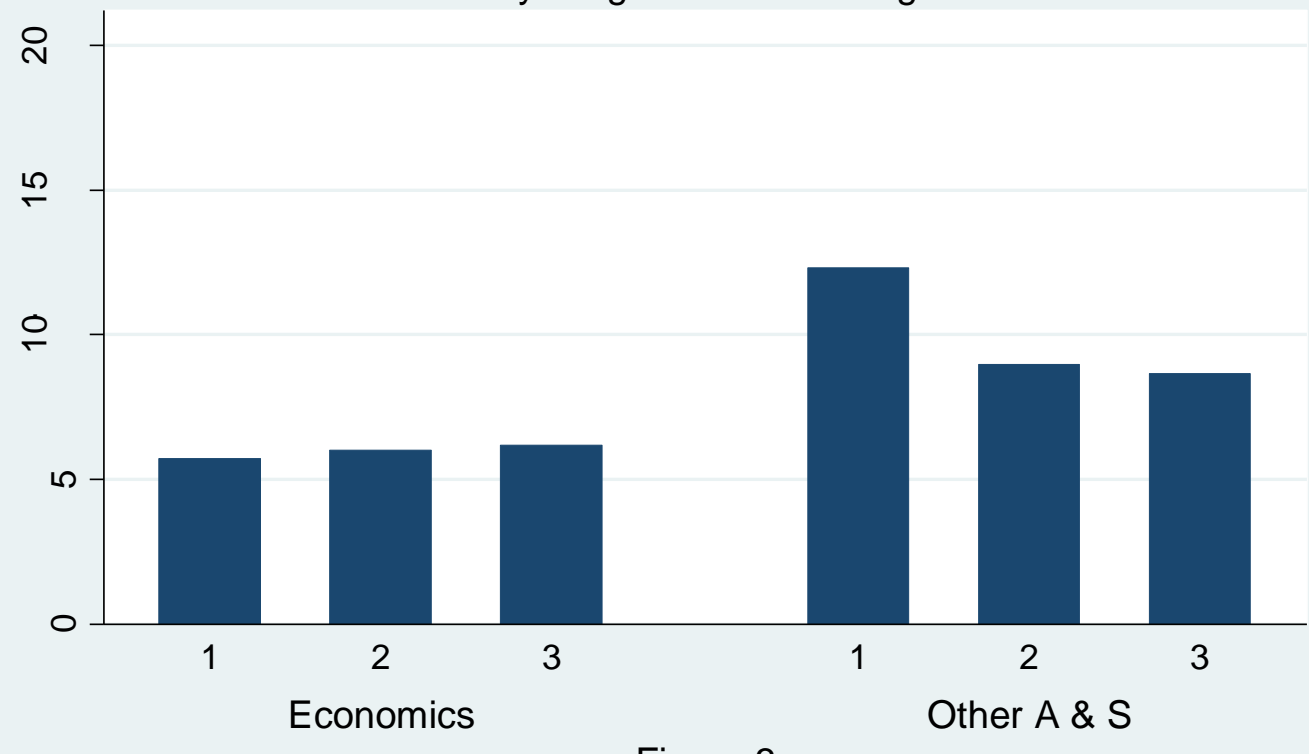

Figure 3

1 No Econ 2 Intro Only 3 Intro and Intermediate

\section{Donated to ATN}

By Program and Training

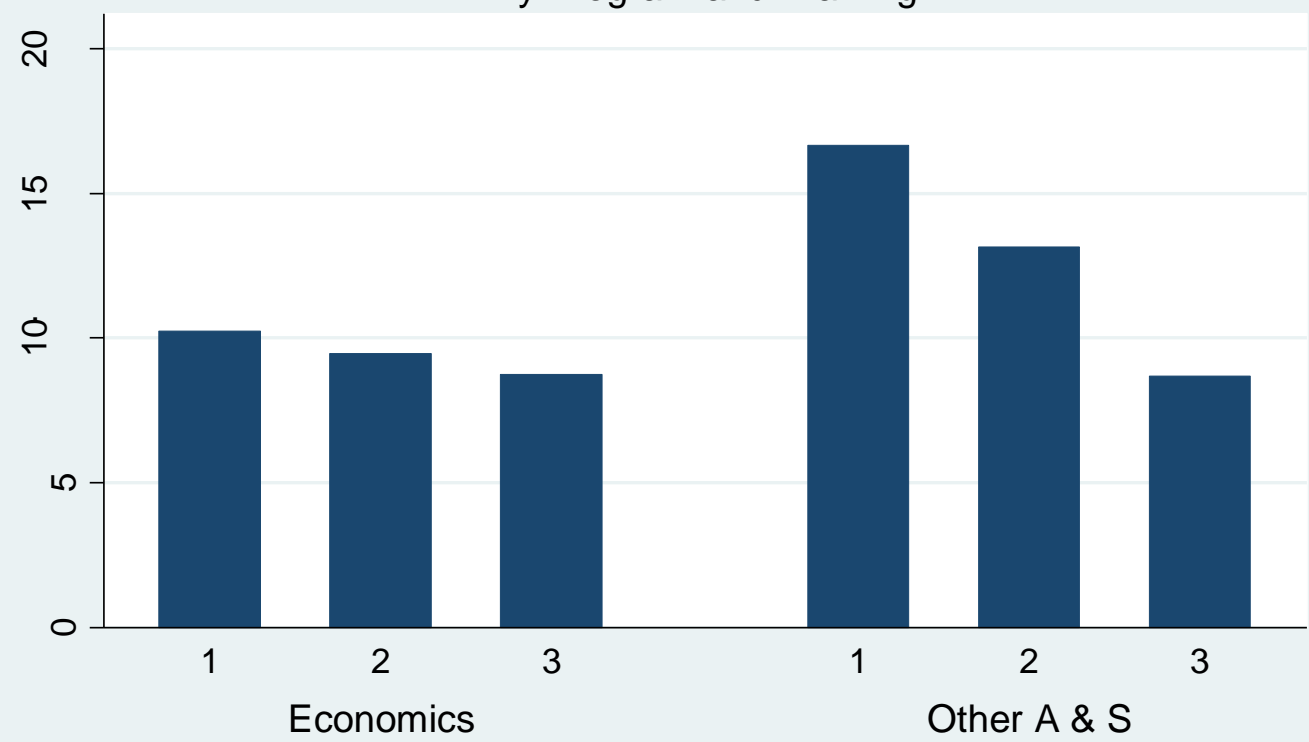

Figure 4

1 No Econ 2 Intro Only 3 Intro and Intermediate 


\title{
Table 1
}

\section{Descriptive Statistics}

\author{
WashPIRG ATN \\ Mean Std. Dev. Mean Std.Dev.
}

$\underline{\text { Time-Invariant }}$

Ever Donated

0.266

0.442

0.340

0.474

Economics Major

0.085

0.279

0.085

0.279

A\&S Non-Major

0.915

0.279

0.915

0.279

Ever Had Intro

0.316

0.465

0.316

0.465

Ever Had Intermediate

0.073

0.260

0.073

0.260

Female

0.609

0.488

0.609

0.488

Year Born

1980.2

1.143

1980.2

1.143

Black

0.020

0.139

0.020

0.139

Asian

0.208

0.406

0.208

0.406

International

0.018

0.134

0.018

0.134

Time Varying

Donated this Quarter

0.111

0.314

0.153

0.360

Has Had Intro (Intro)

0.257

0.437

0.279

0.449

Has Had Intermediate

(Intermediate)

0.038

0.191

0.046

0.208

Freshman

0.168

0.374

0.236

0.424

Sophomore

0.271

0.444

0.106

0.308

Junior

0.325

0.468

0.349

0.477

Senior

0.237

0.425

0.309

0.462 
Table $2^{1}$

\title{
Likelihood of Donating
}

\author{
Pooled Data
}

WashPIRG

(1)

RE
(3)

FE
ATN

(5)

(6)

(4)

RE

RE

FE

\begin{tabular}{|c|c|c|c|c|c|c|}
\hline Econ & $\begin{array}{l}-0.0556 \\
(7.35)^{* *}\end{array}$ & $\begin{array}{l}-0.0443 \\
(5.42)^{* *}\end{array}$ & & $\begin{array}{l}-0.0642 \\
(7.77)^{* *}\end{array}$ & $\begin{array}{l}-0.0358 \\
(3.71)^{* *}\end{array}$ & \\
\hline Intro & & $\begin{array}{l}-0.0209 \\
(5.58)^{* *}\end{array}$ & $\begin{array}{l}-0.0173 \\
(3.30)^{* *}\end{array}$ & & $\begin{array}{l}-0.0287 \\
(5.36)^{* *}\end{array}$ & $\begin{array}{r}-0.016 \\
(1.90)\end{array}$ \\
\hline Intermediate & & $\begin{array}{c}0.0003 \\
(0.06)\end{array}$ & $\begin{array}{c}-0.0009 \\
(0.12)\end{array}$ & & $\begin{array}{l}-0.0227 \\
(2.64)^{* *}\end{array}$ & $\begin{array}{c}-0.024 \\
(2.04)^{*}\end{array}$ \\
\hline Female & $\begin{array}{l}-0.0235 \\
(4.31)^{* *}\end{array}$ & $\begin{array}{c}-0.025 \\
(4.58)^{* *}\end{array}$ & & $\begin{array}{l}-0.0363 \\
(6.25)^{* *}\end{array}$ & $\begin{array}{l}-0.0388 \\
(6.66)^{* *}\end{array}$ & \\
\hline Yrborn & $\begin{array}{c}0.0167 \\
(5.89)^{* *}\end{array}$ & $\begin{array}{c}0.0158 \\
(5.57)^{* *}\end{array}$ & & $\begin{array}{c}0.0203 \\
(6.33)^{* *}\end{array}$ & $\begin{array}{c}0.019 \\
(5.93)^{* *}\end{array}$ & \\
\hline Black & $\begin{array}{l}-0.0675 \\
(4.79)^{* *}\end{array}$ & $\begin{array}{l}-0.0676 \\
(4.80)^{* *}\end{array}$ & & $\begin{array}{l}-0.0524 \\
(2.85)^{* *}\end{array}$ & $\begin{array}{l}-0.0531 \\
(2.88)^{* *}\end{array}$ & \\
\hline Asian & $\begin{array}{c}-0.0706 \\
(13.19)^{* *}\end{array}$ & $\begin{array}{c}-0.0689 \\
(12.88)^{* *}\end{array}$ & & $\begin{array}{c}-0.0809 \\
(13.62)^{* *}\end{array}$ & $\begin{array}{c}-0.0786 \\
(13.21)^{* *}\end{array}$ & \\
\hline International & $\begin{array}{l}-0.0865 \\
(7.11)^{* *}\end{array}$ & $\begin{array}{l}-0.0862 \\
(7.10)^{* *}\end{array}$ & & $\begin{array}{l}-0.1075 \\
(7.35)^{* *}\end{array}$ & $\begin{array}{l}-0.1078 \\
(7.39)^{* *}\end{array}$ & \\
\hline $\begin{array}{l}\text { N Obs. } \\
\text { N Students }\end{array}$ & $\begin{array}{c}65044 \\
8743\end{array}$ & $\begin{array}{c}65044 \\
8743\end{array}$ & $\begin{array}{c}65044 \\
8743\end{array}$ & $\begin{array}{c}46812 \\
8557\end{array}$ & $\begin{array}{c}46812 \\
8557\end{array}$ & $\begin{array}{c}46812 \\
8557\end{array}$ \\
\hline
\end{tabular}

\footnotetext{
${ }^{1}$ Linear probability models with z-scores in parentheses. Models also include dummy variables indicating quarter, sophomore, junior and senior. RE: Random Effects, FE: Fixed Effects. *Significant at 5 percent level, ${ }^{* *}$ Significant at 1 percent level. Bold type: significant at 10 percent level.
} 
Table $3^{1}$

\title{
Likelihood of Donating
}

\author{
By Major
}

WashPIRG

Economics Arts \& Sciences $\quad$ Economics $\quad$ Arts \& Sciences

(1)

(2)

(3)

(4)

(5)

(6)

(7)

(8)

$\begin{array}{lllllll}\text { RE } & \text { FE } & \text { RE } & \text { FE } & \text { RE } & \text { FE }\end{array}$

\begin{tabular}{|c|c|c|c|c|c|c|c|c|}
\hline Intro & $\begin{array}{l}-0.0 \\
(0.4)\end{array}$ & $\begin{array}{l}-0.00 \\
(0.21)\end{array}$ & $\begin{array}{c}-0.0234 \\
(5.6)^{* *}\end{array}$ & $\begin{array}{l}-0.020 \\
(3.4)^{* *}\end{array}$ & $\begin{array}{c}-0.0144 \\
(1.01)\end{array}$ & $\begin{array}{c}-0.0055 \\
(0.32)\end{array}$ & $\begin{array}{c}-0.0274 \\
(4.7)^{* *}\end{array}$ & $\begin{array}{c}-0.0114 \\
-1.13\end{array}$ \\
\hline \multirow{2}{*}{$\begin{array}{l}\text { Intermedia } \\
\text { te }\end{array}$} & -0.0 & 0.001 & -0.0324 & -0.037 & 0.0026 & 0.015 & -0.073 & -0.079 \\
\hline & $(0.2)$ & (0.09) & (1.70) & $(2.03)^{*}$ & $(0.20)$ & $(0.94)$ & $(3.2)^{* *}$ & $(3.5)^{* *}$ \\
\hline Female & $\begin{array}{l}-0.02 \\
(2.0) *\end{array}$ & & $\begin{array}{c}-0.0255 \\
(4.4)^{* *}\end{array}$ & & $\begin{array}{c}-0.0207 \\
(1.36)\end{array}$ & & $\begin{array}{c}-0.0407 \\
(6.6)^{* *}\end{array}$ & \\
\hline Yrborn & $\begin{array}{l}-0.0 \\
(0.1)\end{array}$ & & $\begin{array}{c}0.017 \\
(5.7)^{* *}\end{array}$ & & $\begin{array}{l}0.005 \\
(0.52)\end{array}$ & & $\begin{array}{l}0.0204 \\
(6.0)^{* *}\end{array}$ & \\
\hline Black & $\begin{array}{l}0.12 \\
(1.8)\end{array}$ & & $\begin{array}{c}-0.0731 \\
(5.1)^{* *}\end{array}$ & & $\begin{array}{c}-0.0017 \\
(0.02)\end{array}$ & & $\begin{array}{c}-0.0544 \\
(2.9)^{* *}\end{array}$ & \\
\hline Asian & $\begin{array}{c}-0.06 \\
(4.5)^{* *}\end{array}$ & & $\begin{array}{c}-0.07 \\
(12)^{* *}\end{array}$ & & $\begin{array}{c}-0.0719 \\
(4.8)^{* *}\end{array}$ & & $\begin{array}{l}-0.079 \\
(12)^{* *}\end{array}$ & \\
\hline Internat & $\begin{array}{c}-0.043 \\
(2.1)^{*}\end{array}$ & & $\begin{array}{l}-0.105 \\
(7.2)^{* *}\end{array}$ & & $\begin{array}{c}-0.0635 \\
(2.44)^{*}\end{array}$ & & $\begin{array}{c}-0.1299 \\
(7.4)^{* *}\end{array}$ & \\
\hline N Obs. & 5903 & 5903 & 59141 & 59141 & 4180 & 4180 & 42632 & 42632 \\
\hline N Students & 741 & 741 & 8002 & 8002 & 735 & 735 & 7822 & 7822 \\
\hline
\end{tabular}

\footnotetext{
${ }^{1}$ Linear probability models with z-scores in parentheses. Models also include dummy variables indicating quarter, sophomore, junior and senior. RE: Random Effects, FE: Fixed Effects. *Significant at 5 percent level, ${ }^{* *}$ Significant at 1 percent level. Bold type: significant at 10 percent level.
} 
Table $4^{1}$

\section{Likelihood of Donating}

\section{Interacted Specifications Full Sample}

WashPIRG

(1)

RE

Econ

$-0.0537$

$(5.56)^{* *}$

Intro

$\begin{array}{llll}-0.0233 & -0.0163 & -0.0266 & -0.0072 \\ (5.62)^{* *} & (2.74)^{* *} & (4.60)^{* *} & (0.72)\end{array}$

Intermediate

$\begin{array}{cccc}-0.0323 & -0.0384 & -0.0723 & -0.0766 \\ (1.7) & (2.15)^{*} & (3.20)^{* *} & (3.45)^{* *}\end{array}$

E_Intro

0.0143

(1.72)

0.0119

(1.08)

$-0.0148$

(1.03)

$-0.0316$

(1.77)s

E_Intermediate

0.0319

0.0364

(1.89)

0.0589

$(2.41)^{*} \quad(2.58)^{* *}$

Observations

Number of id
$65044 \quad 65044$

$8743 \quad 8743$
$46812 \quad 46812$

$8557 \quad 8557$

\footnotetext{
${ }^{1}$ Linear probability models with z-scores in parentheses. Models also include year born and dummy variables indicating quarter, sophomore, junior and senior female, black, and international. RE: Random Effects, FE: Fixed Effects. *Significant at 5 percent level, **Significant at 1 percent level. Bold type: significant at 10 percent level.
} 
Table $5^{1}$

\section{Likelihood of Donating \\ Interacted Specifications \\ Freshman at Least 3 Quarters}

WashPIRG ATN

(1)

$\mathrm{RE}$
(2)

FE
(3)

RE $\quad$ FE

\begin{tabular}{|c|c|c|c|c|}
\hline Econ & $\begin{array}{l}-0.0515 \\
(3.38)^{* *}\end{array}$ & & $\begin{array}{c}-0.0194 \\
(0.92)\end{array}$ & \\
\hline Intro & $\begin{array}{l}-0.0283 \\
(4.10)^{* *}\end{array}$ & $\begin{array}{l}-0.0276 \\
(3.13)^{* *}\end{array}$ & $\begin{array}{l}-0.0215 \\
(2.13)^{*}\end{array}$ & $\begin{array}{c}-0.0117 \\
-0.83\end{array}$ \\
\hline Intermediate & $\begin{array}{l}-0.1299 \\
(2.85)^{* *}\end{array}$ & $\begin{array}{c}-0.1379 \\
(3.32)^{* *}\end{array}$ & $\begin{array}{c}-0.0657 \\
(1.26)\end{array}$ & $\begin{array}{c}-0.0357 \\
(0.79)\end{array}$ \\
\hline E_Intro & $\begin{array}{c}0.0089 \\
(0.75)\end{array}$ & $\begin{array}{c}0.0083 \\
(0.55)\end{array}$ & $\begin{array}{c}-0.0268 \\
(1.28)\end{array}$ & $\begin{array}{c}-0.0345 \\
(1.43)\end{array}$ \\
\hline E_Intermediate & $\begin{array}{c}0.125 \\
(2.66)^{* *}\end{array}$ & $\begin{array}{c}0.1316 \\
(3.02)^{* *}\end{array}$ & $\begin{array}{c}0.0476 \\
-0.87\end{array}$ & $\begin{array}{c}0.0275 \\
-0.55\end{array}$ \\
\hline $\begin{array}{l}\text { Observations } \\
\text { Number of id }\end{array}$ & $\begin{array}{c}20028 \\
2600\end{array}$ & $\begin{array}{c}20028 \\
2600\end{array}$ & $\begin{array}{c}15426 \\
2592\end{array}$ & $\begin{array}{c}15426 \\
2592\end{array}$ \\
\hline
\end{tabular}

\footnotetext{
${ }^{1}$ Linear probability models with z-scores in parentheses. Models also include year born and dummy variables indicating quarter, sophomore, junior and senior female, black, and international. RE: Random Effects, FE: Fixed Effects. *Significant at 5 percent level, **Significant at 1 percent level. Bold type: significant at 10 percent level.
} 